\title{
Awareness and Use of Serials in an African University Library: Faculty and Students' Perspective
}

\author{
Erica Nutsupkui, Christopher M. Owusu-Ansah \\ University of Education, Winneba, Kumasi Campus, Ghana-West Africa \\ ericanutss@yahoo.com,chrisoansah@gmail.com
}

\begin{abstract}
The purpose of this study was to examine the use of print serials by students and faculty members of a satellite campus of the University of Education, Winneba. Specifically, this study sought to determine the level of awareness and use of serials among faculty and graduate students, and how this affect their perception of the value of print serials in teaching and learning. The study made use of survey research methods through the use of questionnaires. The population of the study consisted of 165 faculty members and 97 graduate students, with an eventual return rate of $66 \%$ each, respectively. The findings of the study revealed that both faculty and graduate students were, relatively, aware of the print serial collection in the library. However, despite this awareness, they used print serials, relatively, less frequently. Again, the study established that both faculty and students have significant positive perceptions on the usefulness of print serials in their teaching, learning and research roles. We recommend to librarians to create awareness of print serial collections while updating the collection, and enhance the positive perception of print serials by demonstrating, through outcome measures, how the use of print serials can be beneficial to the academic and research community.
\end{abstract}

Keywords: Academic Libraries, Journals, Research and Publications, Serials, University of Education, Winneba

\section{Introduction}

Academic libraries are valued for their expertise in providing current information resources such as serials to complement teaching, learning and research (Blackwell, 2014). Academic and research libraries acquire, organize, store, retrieve and disseminate information contained in serials for researchers, educators, students and other interested persons in their various disciplines. There are many kinds of serials. These include newspapers, magazines, newsletters, accessions, journals, indexes, abstract, reports, proceedings and transactions of societies and so on. Serials are a publication in any medium issued in successive parts bearing numerical or chronological designations and intended to be continued indefinitely."Despite their potential for providing current information to boost empirical research, lack of adequate funds coupled with high subscription rates, and the digital transformation of the scholarly communication process have immensely affected the development of print serial collections in academic libraries globally (Calhoun, 2014:36; Akinbode, 2011). Previous studies have found compelling evidence of the dwindling patronage of all print resources in academic libraries including print serials. Ogunniyi et al. (2011) attribute the low use of serials to the perception that print journals, for instance, are old and scanty. Liu (2011) identifies a number of factors responsible for the paradigm shift in print collection development to electronic resources. These include electronic resources' features for reference linking to additional resources, searching capability, currency, availability, and ease of access. According to the author, other advantages of electronic resources include ease of access, ease of printing, and ease of searching. Despite these strong reasons for an increasingly overwhelming preference for electronic resources, other experts are of the view that academic libraries must emphasise the superior value of their print resources as marketing tools (Dilevko \& Gottlieb, 2002). Furthermore, these values include depth of treatment, portability, flexibility and the educative experience created for students. Indeed, Liu (2011) urges caution in the mad rush preference for online resources as mines of research material may never be available in the digital realm. The literature is replete with studies in often highly technologically advanced societies where preferences for digital information resources are very high, and by implication the use of electronic serials is the order of the day. However, most academic libraries in the present context continue to stock print serial collections due to continued demand for the print format. Consequently, this study examines the awareness and use of print serials by students and faculty members of an African university. Specifically, the study explores the awareness and use of print serials among faculty and graduate students; and, how awareness and use of print serials has reflected in their perceptions on the usefulness of print serials in teaching, learning and research. 
Research Context: The study was conducted at a large multi-campus public university in Ghana, the University of Education, Winneba (UEW). The University was established in September, 1992 as a University College under PNDC Law 322. On May, 2004 the University of Education Act, Act 672 was enacted to upgrade the status of the University College of Education to the status of a full university and to provide related matters. The University has three satellite campuses. They are the Ajumako campus, College of Agriculture Education, in Mampong and the College of Technology Education, Kumasi (COLTEK), which is the study setting (UEW Dairy, 2014). As the second largest campus, the College of Technology Education, Kumasi (COLTEK) of the University of Education, Winneba is charged with the responsibility of producing professional educators in technical, vocational, and management education to spearhead a new national vision of education aimed at redirecting Ghana's efforts along the path of rapid economic and social development. The Library of the College of Technology Education, Kumasi (COLTEK) has two senior professional librarians who are management staff, three senior staff who are paraprofessionals and about fifteen junior staff. One senior staff is in charge of the Serials Section. The Library has a seating capacity of one hundred and fifty-six (156) readers. The Serial Section acquires, organises, manages and makes available a number of serials which includes journals, newspapers, magazines, reports, proceedings, among others. The journal subscription is one hundred and eighty (180) titles. Newspaper subscription is six and these include two daily national newspapers with the rest being non-daily newspapers. In addition to these, a number of magazines on different themes are collected.

\section{Literature Review}

It is generally acknowledged that serials play an important role in research. According to Wiser (2014) serials will continue to make a special impact on the scholarly community as they contain the most current and vital information on various disciplines. The role of serial publications in scholarly communication has been well documented. Aina (2006) confirms that a journal is the principal medium for reporting research findings because of the wide publicity it gives to the author. Information in journals is a product of research and may never appear again in any other form (Nwalo, 2001). This accounts for the great importance attached to serial publications by libraries and researchers in Africa. Serials are sources of current information and have several other contributions to make to education. Serials can be regarded as the nerve-centre of any university library because they contain the most up-to-date information on research and knowledge. Agbaje (2002) also concluded that serials constitute one of the most, if not the most important information resource of the information age. Serials are invaluable information materials for academic work. According to Akinbode (2011) "nearly all the disciplines of study make use of serials particularly the scholarly journals, as a primary means of communicating new research results, new theories, and new critical approaches". Most academic libraries, according to Akinbode (2011) restrict, at least, their current serials holdings and sometimes the whole collection to use in the library only so as to ensure that current issues are accessible and secured because missing issues are difficult to replace. Other libraries also restrict their serials to researchers. Aghadiuno, Agbo and Onyekweodiri's (2015) study of two university libraries in North-Central Nigeria regarding access to their serials collection found that the serials section are open to academic staff and postgraduate students.

To ensure effective use of serials, the needs of the users should be determined. Information from the patrons on their expectation of serials, as observed by Anunobi, Nwakwuo and Ezejiofor (2010), would no doubt make the library feel the pulse of the users. Tedd (2006) reports that journals with a practical bias appeared to be more patronised by graduate students of the University of Wales, Aberystwyth in their dissertations than more research-oriented journals with high impact factors. Bhat (2014) found that majority (80\%) of faculty members of an engineering college in India make use of print periodicals in their teaching and for obtaining new knowledge in their field of expertise. Other users, however, use non-academic print serials for dual purposes of recreation and gaining new knowledge (Madukoma et al., 2013). It is, therefore, important for serial librarians to consider the eclectic uses of serials and make provision for diverse user interests in their collection development. While the use of serials by academics and researchers in developed countries is well-recognised, their use and acceptance by universities in developing countries are still mixed (Ahmed, 2011). Furthermore, the reliance on books for research information among student researchers and some faculty members in Africa is a worrying trend, as current research findings are available in serials. Ajala (2007) opines that serials are of little use than monographs to both undergraduate and postgraduate 
students. On the contrary, Ajala (2007) found in another study that doctoral students found serials more useful because of their skill, experience and knowledge. These findings suggest the need for training and reorientation on the benefit of serials researchers to boost research capable of promoting development in African universities.

In studies where serial use was noted to be popular, several obstacles have impeded their use. Akinbode (2011) found that faculty members and postgraduate students in Nigeria spend more of their time reading publications in serials, such as scholarly journals and technical reports of specialised organisations and societies, than from books and monographs. For instance the Nigerian university of Agriculture Libraries, according to Salaam (2001), had not fared well in their provision of relevant and adequate journals for research and that this has affected their postgraduate students as they did not have sufficient access to their university libraries serials collection. The situation is not different from Ghana. The use of serial publications in Ghana has been reported by a number of researchers (Arkaifie, 1997; Kisiedu, 1999; Adika, 2003; and Dadzie 2005). These studies report low to average usage of serials in Ghanaian universities. Lawoe (2006) found that serials were moderately used by all categories of library users at the Kwame Nkrumah University of Science and Technology. Arkaifie (1997) recounts the gloomy state of serial collections in Ghanaian universities; remarking that "faculty members in academic libraries in Ghana still complain they do not have enough periodicals despite improvement in subscription level from the late 1980s." This has led to many universities in Ghana subscribing to electronic serials. According to Dadzie (2005), universities in Ghana provide access to databases of full-text journal articles and abstracts. Despite the availability of electronic resources in response to the need for more current journals, Dadzie (2005) observes that while usage of some internet resources is very high, the use of electronic journals is quite low in academic libraries. She attributes the low patronage to inadequate awareness of their existence. It may, therefore, be concluded that whether a library provides electronic or print journals, the most important factor for use is awareness and knowledge of these resources.

\section{Methodology}

This study made use of survey research methods. The study setting was the College of Technology Education (COLTEK), a satellite campus of the University of Education, Winneba. The campus was selected because no similar work in the area of this research has been published in the literature. Furthermore, the study site was accessible to the researcher thereby making data collection feasible. The population of the study consists of faculty members and graduate students. Faculty members were selected due to their need for current information in journals for research and publication activities. Similarly, graduate students were included in the study because they may also use researched information mostly found in journals to complete their theses and dissertations. The total population of graduate students in the study university was 97 . Alreck and Settle (1985) are of the view that in ordinary conditions $10 \%$ of the total sample is adequate. However, ten percent $(10 \%)$ of 97 was considered inadequate for a sample size, and as a result a census of the whole population was undertaken. The population of faculty members at COLTEK was 165 as at the time of conducting the study. Similarly, since the population of faculty members at COLTEK was not considered too large for the study, a census of faculty members at the campus was also used for the study.

A self-administered closed-ended questionnaire was designed for the study. The questionnaire consisted of four sections: Section A involved information on respondents' demographic data; section B comprised of questions on awareness of serial publications in the library; Section C covered use of serials by faculty and students; while Section D covered perception of the usefulness of serial publications in teaching and learning. The survey component of the study was conducted within a period of three weeks within the month of March 2014. Completed questionnaire by graduate students were collected immediately. However, for faculty members, the questionnaires were deposited in their official mail boxes and collected once it had been completed within the three week period. At the end of the survey, $64(66 \%)$ students returned validly completed questionnaire. In respect of faculty, 109 questionnaires representing 66 per cent were retrieved for the study. Data was analysed using the statistical package for the social sciences (SPSS) and the findings presented in cross-tabulation form 


\section{Findings}

Background of respondents: The demographic backgrounds of the respondents are presented in Tables 1 and 2.

Gender distribution of respondents: Respondents were asked to indicate their gender. Table 1 shows the gender distribution of the respondents.

Table 1: Gender Distribution of Respondents

\begin{tabular}{llllll}
\hline \multirow{2}{*}{ Status } & $\begin{array}{l}\text { Gender } \\
\text { Male }\end{array}$ & & Female & & TOTAL \\
& F & $\mathbf{( \% )}$ & F & \% & \\
\hline Postgraduate & 32 & 62.7 & 19 & 37.3 & 51 \\
Faculty & 70 & 70.7 & 29 & 29.3 & 99 \\
\hline
\end{tabular}

Source: Field Work, 2014

Gender distribution of respondents from Table 1 above shows that, 32 faculty members representing $62.7 \%$ and 67 graduate students representing $70.7 \%$ were males. On the other hand 19 postgraduate students and 28 faculty members representing $37.3 \%$ and $29.5 \%$ were females. Thus majority of respondents were males.

Faculty/Department of respondents: The study sought to identify the department to which the respondents belonged. The departmental affiliations of the respondents are presented in Table 1.2:

Table 2: Faculty/Department of Respondents

\begin{tabular}{|c|c|c|c|c|}
\hline \multirow{3}{*}{ Faculty / Department } & \multicolumn{4}{|c|}{ Status } \\
\hline & \multicolumn{2}{|c|}{ Faculty } & \multicolumn{2}{|c|}{ Postgraduate } \\
\hline & $\mathbf{F}$ & $\%$ & $\mathbf{F}$ & $\%$ \\
\hline Accounting & 10 & 10.2 & 20 & 39.2 \\
\hline Management & 18 & 18.4 & 30 & 58.8 \\
\hline Technology & 30 & 30.6 & 0 & 0 \\
\hline ICT & 20 & 20.4 & 0 & 0 \\
\hline Interdisciplinary Studies & 19 & 19.4 & 1 & 2.0 \\
\hline Other & 2 & 1.0 & 0 & 0 \\
\hline Total & 99 & 100 & 51 & 100 \\
\hline
\end{tabular}

Source: Field Work, 2014

From Table 2 it can be seen that 30 faculty representing 30.6\% indicated Technology department. For the graduate student respondents, 30 representing 58.8\% indicated the Department of Management. Only one graduate student respondent $(2.0 \%)$ indicated Interdisciplinary Studies. No faculty member indicated Interdisciplinary Studies.

Awareness of serials among faculty and graduate students: To promote the use of any service, it is very crucial that awareness of that service is created (Bentil, 2011). It is against this background that respondents were asked to indicate their level of awareness of serial publications in the library. The responses given provide an insight into their level of awareness. It is evident from Table 3 that majority of faculty respondents (64) and over half of the postgraduate students (36) representing $64.6 \%$ and $70.6 \%$ respectively, indicated their awareness of the serials publications of the COLTEK Library. Faculty members intimated that they got to know about the publications through friends, notices, and the library website, while graduate students indicated that they got to know about them mainly through orientation and colleagues. 
Table 3: Awareness of serials

\begin{tabular}{lllll}
\hline \multirow{2}{*}{ Awareness } & Status & \multicolumn{2}{c}{ Postgraduate } \\
& Faculty & \multicolumn{3}{c}{ \% } \\
& F & \% & F & \% \\
& 64 & 64.6 & 36 & 70.6 \\
Yes & 33 & 33.3 & 15 & 29.4 \\
No & 2 & 2.2 & 0 & 0 \\
Total & 99 & 100 & 51 & 100 \\
\hline
\end{tabular}

Source: Field Work, 2014

Awareness of types of serials: Further inquiry was done to determine respondents' awareness of the various types of serials available in the library. For this reason, those who were aware of the serial collections were asked to indicate the various types of serials they were aware of (See Table 4).

Table 4: Awareness of the various types of serial

\begin{tabular}{|c|c|c|c|c|c|c|c|c|}
\hline \multirow{4}{*}{$\begin{array}{l}\text { Serial } \\
\text { Publications }\end{array}$} & \multicolumn{8}{|c|}{ AWARENESS } \\
\hline & \multicolumn{4}{|c|}{ Faculty } & \multicolumn{4}{|c|}{ Postgraduate } \\
\hline & \multicolumn{2}{|c|}{ Yes } & \multicolumn{2}{|l|}{ No } & \multicolumn{2}{|c|}{ Yes } & \multicolumn{2}{|l|}{ No } \\
\hline & $\mathbf{F}$ & $\%$ & $\mathbf{F}$ & $\%$ & $\mathbf{F}$ & $\%$ & $\mathbf{F}$ & $\%$ \\
\hline Journals & 62 & 96.9 & 2 & 6.1 & 35 & 89.7 & 4 & 10.3 \\
\hline Newspapers & 74 & 94.9 & 4 & 5.1 & 30 & 76.9 & 9 & 23.1 \\
\hline Magazines & 38 & 48.7 & 40 & 51.3 & 19 & 48.7 & 20 & 51.3 \\
\hline Annual Reports & 43 & 55.1 & 35 & 44.9 & 6 & 15.4 & 33 & 84.6 \\
\hline
\end{tabular}

Source: Field Work, 2014

The findings revealed that 64 faculty members and 35 graduate students representing $82.1 \%$ and $89.7 \%$ respectively were aware of the journals in the library. Concerning the newspapers, 74 faculty members and 30 graduate students representing $94.9 \%$ and $76.9 \%$ respectively were aware of them. Respondents were aware of magazines and annual reports as 38 of faculty members representing $48.7 \%$ and 19 graduate students representing $48.7 \%$. Forty-three faculty members and 6 graduate students representing $55.1 \%$ and $15.4 \%$ respective were aware of annual reports.

Frequency of use serials by faculty and students: Faculty and students are expected to make use of the publications available in the library for various academic exercises. For this reason, the respondents who used the serials were asked to indicate how often they used the materials as shown in the Table below:

From Table 5 above 23 faculty members representing $23.2 \%$ indicated that they use journals monthly while 36 representing $36.4 \%$ indicated that they never use them. Nineteen representing $19.2 \%$ indicated that they use proceedings once in a while and 49 representing $49.5 \%$ has never used it. They also indicated that 29 representing 29.3\% used annual reports once in a while and 41 representing $41.4 \%$ had never used it. Twenty-four representing $24.2 \%$ indicated that they used magazines once in a while and 41 representing $41.4 \%$ indicated that they had never used it. Newspapers were mostly used by respondents who indicated 37 representing $41.6 \%$ used it daily while 32 representing $37.4 \%$ never used it. 
Table 5: Frequency of use of serials by faculty members

\begin{tabular}{|c|c|c|c|c|c|c|c|c|c|c|}
\hline \multirow[b]{2}{*}{$\begin{array}{l}\text { Frequency } \\
\text { use }\end{array}$} & \multicolumn{2}{|c|}{$\begin{array}{l}\text { Faculty } \\
\text { Type of serial } \\
\text { Journal }\end{array}$} & \multicolumn{2}{|c|}{ Proceedings } & \multicolumn{2}{|c|}{ Annual report } & \multicolumn{2}{|c|}{ Magazines } & \multicolumn{2}{|c|}{ News Papers } \\
\hline & $\mathbf{F}$ & $\%$ & $\mathbf{F}$ & $\%$ & $\mathbf{F}$ & $\%$ & $\mathbf{F}$ & $\%$ & $\mathbf{F}$ & $\%$ \\
\hline Daily & 1 & 1.0 & - & - & - & - & - & - & 37 & 37.4 \\
\hline Once a week & 4 & 4.0 & 1 & 1.0 & 2 & 2.0 & - & - & 2 & 2.0 \\
\hline Twice a week & 9 & $9.1 \%$ & 1 & 1.0 & 1 & 1.0 & 3 & 3.0 & 2 & 2.0 \\
\hline Monthly & 23 & 23.2 & 14 & 14.1 & 7 & 7.1 & 12 & 12.1 & 1 & 1.0 \\
\hline Once in a while & 19 & 19.2 & 19 & 19.2 & 29 & 29.3 & 24 & 24.2 & 15 & 15.2 \\
\hline Never & 36 & 36.4 & 49 & 49.5 & 41 & 41.4 & 41 & 41.4 & 32 & 32.3 \\
\hline No Response & 7 & 7.1 & 15 & 15.2 & 19 & 19.2 & 19 & 19.2 & 10 & 10.1 \\
\hline Total & 99 & 100 & 99 & 100 & 99 & 100 & 99 & 100 & 99 & 100 \\
\hline
\end{tabular}

Source: Field Work, 2014

Table 6: Frequency of use of serials by graduate students

\section{Graduate students}

Type of serial

Journal $\quad$ Proceedings Annual report Magazines News Papers

\begin{tabular}{lllllllllll} 
Freq. of use & $\mathbf{F}$ & $\mathbf{0}$ & $\mathbf{F}$ & $\mathbf{\%}$ & $\mathbf{F}$ & $\mathbf{\%}$ & $\mathbf{F}$ & $\mathbf{\%}$ & $\mathbf{F}$ & $\mathbf{\%}$ \\
\hline Daily & - & - & 1 & 2.0 & - & - & - & - & 20 & 39.2 \\
Once a week & 2 & 3.9 & - & - & 1 & 2.0 & - & - & 1 & 2.0 \\
Twice a week & 1 & 2.0 & - & - & 1 & 2.0 & 1 & 2.0 & 1 & 2.0 \\
Monthly & 7 & 13.7 & 2 & 3.9 & 2 & 3.9 & 5 & 9.8 & 1 & 2.0 \\
Once in a while & 23 & 45.1 & 3 & 5.9 & 2 & 3.9 & 15 & 29.4 & 6 & 11.8 \\
Never & 14 & 27.5 & 26 & 51.0 & 30 & 58.8 & 18 & 35.3 & 13 & 25.5 \\
No Response & 4 & 7.8 & 19 & 37.3 & 15 & 29.4 & 12 & 23.5 & 9 & 17.6 \\
Total & 51 & 100 & 51 & 100 & 51 & 100 & 51 & 100 & 51 & 100 \\
\hline
\end{tabular}

Source: Field Work, 2014

Twenty-three graduate students representing 45.1\% indicated that they use journals once in a while and 14 representing $27.5 \%$ indicated that they never use them. Three representing 5.9\% indicated that they use proceedings once in a while and 26 representing $51.0 \%$ has never used it. They also indicated that 2 representing 3.9\% used annual reports once in a while and 30 representing $58.8 \%$ had never used it. Fifteen students representing $29.4 \%$ indicated that they used magazines once in a while and 18 representing $35.3 \%$ indicated that they had never used it. Similar to faculty members, newspapers were mostly used by the graduate students who indicated that 20 representing $47.6 \%$ used it daily while 13 representing $31 \%$ never used it.

Usefulness of the serials to faculty and graduate students: Respondents were also asked to indicate the usefulness of the serial collections. This question was meant to elicit from both faculty members and students their perception on the role of serial resources in teaching and learning. Table 1.7 depicts their responses: 
Table 7: Usefulness of the serial collections

\begin{tabular}{lllll}
\hline Level of usefulness & $\begin{array}{l}\text { Status } \\
\text { Faculty }\end{array}$ & \multicolumn{3}{c}{ Postgraduate } \\
& F & \% & F & \% \\
\hline Very useful & 49 & 49.5 & 17 & 33.3 \\
Useful & 17 & 17.2 & 15 & 29.4 \\
Moderately useful & 1 & 1.0 & 4 & 3.3 \\
Quite useful & 1 & 1.0 & 1 & 1.3 \\
No response & 31 & 31.3 & 14 & 27.5 \\
Total & 99 & 100 & 51 & 100 \\
\hline
\end{tabular}

Source: Field Work, 2014

From this question, the findings revealed that 49 of faculty members and 17 of graduate students representing $49.5 \%$ and $33.3 \%$ respectively indicated that serial collections were very useful. In addition 17 (17.25\%) faculty members also expressed optimism about the value of serials in their academic activities, while $15(29.4 \%)$ of graduate students also indicated that these resources are important. On the other end of the spectrum, it is important to note that fairly insignificant respondents $2=$ faculty; $5=$ graduate students) indicate that serials are moderately and quite useful respectively. However, it is important to note the high number of faculty respondents $(31=31.3 \%)$ and 14 graduate students $(27.5 \%)$ who chose not to answer the question on the variable of usefulness. It may be surmised from this that these respondents have no basis of judging the usefulness of serials in their teaching and learning activities.

Discussion of Findings: One of the objectives of this study was to find out faculty members' and students' awareness of the serials available at the University Library. From the study it was found out that most of the respondents were aware of the serial publications in the library as well as the variety of serials on offer. This evidence supports the findings of Majid and Tan (2002) who studied the usage of information resources by computer engineering students in Nanyang Technology University in Singapore and found that majority of respondents were aware of the serial publications. However, about $35 \%$ of respondents indicated that they were not aware of the serial publications in the library. This accounted for the low daily patronage of the library as Torma and Vakkari (2004) affirm that knowledge and awareness of accessible resource in a library is a souring prediction of a library's incidence, exploitation and use. Similarly, Sanchez (2004) indicates that effective communication leads to awareness creation and understanding of products and services. The average response indicated that the respondents were very dissatisfied with the publicity of the serial collections since this was rarely undertaken.

Jubb, Rowlands \& Nicholas (2013) opine that the value of the library is not influenced by its resources and facilities but also on the accomplishment of its exploitation and use. The findings of this study indicated that about half of the respondents used the serial publications. This evidence supports that of Brown, Lund and Walton (2007) who state that academic staff and researchers at Loughborough University in UK relied heavily on journals to support their research activities. This, in the researchers' view, could be due to the fact that serials usually contain current information and as such, are indispensable to academic work. Cottrell (2013) opines that journals are "the core of any academic pursuit", without which academic research and writing will be impossible. Again, on the specific purpose for which serials were used, it was discovered in the study that majority of the respondents used serial publications for research purposes. This supports the assertions of Ogunniyi, Akerele and Afolabi (2011) and Cottrell (2013) who opine that journals are useful for completing thesis and dissertations. Miholič and Južnič (2016) assert that journals are the basis for scientific research and communication. Afful-Broni, Owusu-Ansah and Takyi (2016) find in their study that graduate students use journals for their research projects. Alemna, Chifwepa and Rosenberg (2000) note that journals are used by researchers to identify possible topics in order to write future research and to publish the results of completed research. In spite of the relatively higher number of faculty and graduate students that use serials, it is important to note that it is significant that another half do not use the print serial collection. One challenge that may be envisaged for the low use of the serials collection may still be related to awareness of the serials collection and its possible benefits over online journals. 
This study also demonstrates that both faculty and students considerably value and appreciate print serial resources in the academic library. This finding supports that of previous studies. The value of print resources is highlighted by Dilevko and Gottlieb (2002) who point to undergraduate students' positive perceptions of print periodicals in their academic work. The students described the advantages of periodicals as comprehensiveness (i.e ability to view all issues of the journal); accessibility (in contrast to e-journals which may rely on stable Internet connectivity and power); avoiding eye-strain (due to screen resolutions); high cost of printing e-journal articles if one cannot print; and permanence (as against e-journal articles which may be lost due to virus attack or some other mechanical fault). Aharony and Bar-Ilan (2016) confirm that students value academic print resources over electronic resources as print resources aid in higher comprehension of content. He suggests further that users prefer print information resources because they are modelled on the traditional approach to learning. These advantages must be highlighted by academic librarians to their all groups of users in their user education programmes. It is also important for libraries to point out to their users that not all kinds of electronic resources are preferable or relevant to all users (Kapoor, 2010; Dewan, 2012) and, as such, those who still find print resources, such as serials, useful must be encouraged by being made aware of, and updating and expanding the serial collection.

\section{Conclusion and Recommendations}

The purpose of the study was to examine the awareness and use of serials by graduate students and faculty members of the College of Technology Education, Kumasi (COLTEK) of the University of Education, Winneba. The study found that both faculty and graduate students were relatively aware but despite this awareness used serials relatively less frequently. Again the study has established that both faculty and students have significant positive perceptions on the usefulness of serials in their teaching, learning and research roles. However, a major drawback to serials usage is the relatively lower level of awareness among a section of the respondents. In order to sustain the continued positive perception and subsequent use of print serials, we make the following recommendations:

A. In spite of the proliferation of electronic journals, serial librarians must create awareness of print journals to provide choice for users, through innovative marketing techniques. Lawoe (2006), for instance, recommends intensive user education on serials, current awareness and selective dissemination of information (SDI) to improve serials usage in academic libraries. With SDI, serial librarians can compile a research profile of faculty members and provide them with "snapshots" of, for example, new journals or new issues of existing journals. This snapshot may be produced by making photocopies of the cover page and table of contents to selected faculty members who are interested in that research area. These snapshots can be broadcasted to students through social media platforms such as Whatsapp and Facebook.

B. Furthermore, in an effort to sustain the positive perception of serials, it may be necessary for academic librarians in this institution to consider adopting outcome measures to demonstrate the value of serials. There are a number of ideas on demonstrating academic library value (Blackwell, 2014). Citing the author Oakleaf, Blackwell suggests that academic libraries can enhance the positive perception of their serials collection by establishing what users do with the contents and how this use translates into measurable outcomes. Some of these outcomes include how the use of serials supports the wider institutional goals. These include increased student recruitment and enrolment, retention, career success, grade point averages, etc. For instance, librarians must be able to demonstrate, clearly, how the use of serials helps students cut down on cost through the provision of required readings per semester, without which the student will spend more on books. This evidence can result in student retention and justify the continued investment in serials. Finally, librarians must demonstrate the legacy advantage of print serials, as opposed to electronic serials which are subject to the pitfalls of technology (Dilevko and Gottlieb, 2002). Librarians must, therefore, enhance and increase their print serial collection as increased access to scholarly resources leads to improved research output of researchers (Miholič \& Južnič, 2016). 


\section{References}

Adika, G. (2003). Internet use among faculty members of universities in Ghana. Library Review, 52(1), 29-37.

Afebende, G. B. \& Ebaje, A. S. (2008). Utilization of university library facility; a case study of cross River University of technology, Calabar. Nigerian Library and Information Science Trends, 5(1 \& 2), 29-37

Agbaje, A. A. (2002). Great expectations: serials management and information technology. Information Science and technology for library schools in Africa. Eds. E.C. Madu \& M.B. Dirisu. Ibadan: Evi-Coleman Publications. 25-36.

Aghadiuno, C. P., Agbo, A. D. \& Onyekweodiri, N. E. (2015). Accessibility and use of serials and other continuing resources in two university libraries. International Journal of Multidisciplinary Research and Development, 2(5), 93-97.

Aharony, N. \& Bar-Ilan, J. (2016). Students' academic reading preferences: An exploratory study. Journal of Librarianship and Information Science, 2, 1-11.

Ahmed, S. M. Z. (2011). Use of electronic resources by the faculty members in diverse public universities in Bangladesh. The Electronic Library, 31(3).

Aina, L. O. (2006). Resources sharing and serials acquisition in African university libraries: adoption of new strategies. Paper presented at the SCAULWA Conference held at GIMPA, Achimota on $10^{\text {th }}-11^{\text {th }}$, September, 2001.

Ajala 0. I. (2007). Periodical literature use by the pre-final and final undergraduate students in Nigerian universities. Library Review, 54(1).

Akinbode, R. O. O. (2011). Influence of serials management practices and use in libraries on publication output of lectures in Nigerian universities. Ibadan 7-9

Alemna, A. A., Chifwepa, V. \& Rosenberg, D. (2000). African journals: an evaluation of their use in African universities. African Journal of Library, Archives and Information Science, 10(2), 93-111.

Alreck, L. P. \& Settle, R. B (1985). The survey research handbook. Illinois; IRWN 29

Arkaifie, R. (1997). Periodicals subscription under structural adjustment in Ghanaian university libraries: an appraisal. Library Management, 18(7), 318 MCB University Press.

Afful-Broni, A., Owusu-Ansah, C. M. \& Takyi, L. N. (2016). The impact of ICT on graduate students' use of electronic resources: leadership lessons. International Journal of Educational Leadership, 6(1), 117127.

Anunobi, C. V., Nwakwuo, O. P. \& Ezejiofor, V. 0. (2010). Serials acquisition problems in Nigerian Federal University Libraries. International Journal of Library and Information Science, 2(7), 137-142.

Bhat, P. (2014). Use of periodicals in Engineering College Libraries under North Maharashtra University, Jalgaon. International Journal of Library and Information Science, 6(2), 35-39.

Bentil, W. (2011). The Use of Electronic Resources in Ghanaian Universities: a comparative study of the University of Cape Coast and the Central University College. An unpublished Mphil thesis presented to University of Ghana, Legon. 74

Blackwell, L. S. (2014). The value of serials in academic and special libraries. The Serials Librarian, 66, (1-4) (44-48)

Brown, J., Lund, P. \& Walton, G. (2007). Use of E-Journals by Academic Staff and Researchers at Loughtorough University. Available at http.//www.Iboro-acuk./library/about/PDFs/e-journal-survey (Accessed on February 12, 2014).

Calhoun, K. (2014). Exploring digital libraries: foundations, practice, prospects. London: Facet Publishing.

Dadzie, P. S. (2005). Electronic resources: access and usage at Ashesi University College Campus- Wide Information Systems, 22(5), 290-297.

Dewan, P. (2012). Are books becoming extinct in academic libraries? New Library World, 113(1/2), 27-37.

Dilevko, J. \& Gottlieb, L. (2002). Print Sources in an Electronic Age: A Vital Part of the Research Process for Undergraduate Students. The Journal of Academic Librarianship, 28(6), 381-392.

Essilfie, E. K. B. (2009). Access and use of library resources: a case study of the Trinity Theological Seminary Library (unpublished thesis) University of Ghana.

Fayose, P. O. E. (1995). School library resource centers for educational excellence. Ibadan: AENL Educational Publishers. 19

Jubb, M., Rowlands, I. \& Nicholas, D. (2013). Value of Libraries: Relationships between Provision, Usage, and Research Outcomes. Evidence Based Library and Information Practice, 8(2), 139-152.

Kapoor, K. (2010). Print and electronic resources. Program, 44 (1), 59-68 
Kisiedu, C. O. (1999). Barriers in using new information technology in document delivery in the Third World: prospects for the IFLA project in Ghana. Interblending \& Document Supply, 27(3), 108-16.

Lawoe, M. A. (2006). A study of serials use at Kwame Nkrumah University of Science and Technology Library, Kumasi. Ghana Library Journal, 18(1), 25-38.

Liu, Z. (2011). Print vs. electronic resources: A study of user perceptions, preferences, and use. Information Processing and Management, 42, 583-592.

Miholič, P. \& Južnič, P. (2016). The impact of better access to scientific journals on the quality of research work: The case of a small university. Journal of Librarianship and Information Science, 2, 1-11.

Madukoma, E., Onuoha, U. D., Bamidele, I. A. \& Omeluzor, S. U. (2013). Serials use at Babcock University Library, Ilisan-Remo, Ogun State, Nigeria (2008-2012). Information Management and Business Review, 5(9), 471.

Majid, S. \& Tan, A. T. (2002). Usage of information resources by computer engineering students: a case study of Nanyang Technical University, Singapore. Online Information Review, 26(5), 318-325.

Miller, M. L. (1985). Children's access to library systems. Library Quarterly, 51(1), 39.

Nwalo, K. I. N. (2001). Effectiveness of polytechnic libraries in Nigeria. Journal of Librarianship and information Science in Africa, 1(1), 41-65.

Ocholla, D. N. (1996). Information seeking behaviour by academics: a preliminary study. International Information and library Review, 28, 345-358.

Ogunniyi, S. O., Akerele, J. A. \& Afolabi, A. F. (2011). Use of serial publications by the academic staff of school of Arts And Social Sciences in Adeyemi College of Education Ondo State, Nigeria. Available at: http://digitalcommons.unl.edu/libphilprac/497/ (Accessed 28 March 2017).

Ogunrombi, S. A. (1997). Serials Selection and Deselection: a survey of Nigerian University Libraries. African Journal of Library, Archives and Information Science, 7(1), 33.

Salaam, M. O. (2001). Access to serials collection in four Nigerian university libraries. The Serials Librarian, 41(1), 121-126.

Sanchez, P. (2004). Defining Corporate Culture: What Communicators Can Do to Make the Intangible Tangible' by. Communication World, 21(6).

Szilvasy, J. (1996). The use of serial collections. IFLA Publication 3-6

Tedd, L. A. (2006). Use of library and information science journals by master's students in their dissertations: Experiences at the University of Wales Aberystwyth. Aslib Proceedings: New Information Perspective, $58(6), 570$.

The University of Education Winneba Diary. (2014). Accra: JIT Services Limited.

Torma, S. \& Vakkan, P. (2004). Discipline, availability of electronic resources and the use of finish national electronic FINLIB. Information Research, 3(1) Paper 204.

Wiser, J. (2014). The future of serials: a publisher's perspective. Serials Review, 40(4), 238-241. 